\title{
Main areas of land use in municipal entity
}

\author{
Natalia Ovchinnikova ${ }^{1, *}$, Maria Batranyuk $^{1}$, Ekaterina Zhidkova $^{1}$, Yulia Lazebnaya ${ }^{1}$, and \\ Victoria Timofeeva ${ }^{1}$ \\ ${ }^{1}$ Don State Technical University, pl. Gagarina, 1, Rostov-on-Don, 344003, Russia
}

\begin{abstract}
All that man needs for his existence come from the natural environment. Advanced modern technologies often only increase the consumption of natural resources, since the material benefits produced by human labor are made from them. As a natural resource, land is a unique and most valuable source that forms the basis of life and activity for all humankind. All the processes of establishing a human society, which take place in the social, political, economic, communal, industrial and environmental spheres, are directly linked to land resources. This issue is of ongoing global concern. Therefore, the activities of any state must, first and foremost, be aimed at their effective management and protection from the negative impact of natural factors and consequences of human activity.
\end{abstract}

\section{Introduction}

Land resources are those types of resources that are not artificially created and do not have a fixed price. They include the surface of the land that is suitable for human habitation, construction and economic management. However, we must not forget that land resources being essential to the survival of humankind are non-renewable, i.e. their quantity is steadily decreasing as they are used in the national economy.

It has been proved that the productivity and efficiency of land resources of any area is the most affected by natural and climatic conditions of the area. Therefore, the assessment of land quality is carried out in conjunction with all existing environmental conditions for crop growth and development.

The study of this process demonstrates that it is only possible to obtain objective and reliable information on the quality of the land, the most appropriate way to use it to maximize productivity, if all environmental factors are fully analyzed.

\section{Materials and methods}

The main asset of the Rostov region is its land resources. Having large areas of land with natural characteristics that allow its use in the national economy, the Don Region has for a long time increased the level of gross and commercial production of agricultural products.

In terms of gross harvest of grains and sunflower seeds, the Rostov region is among the leading cities of the Russian Federation from year to year [1-2].

\footnotetext{
${ }^{*}$ Corresponding author: donong160875@yandex.ru
} 
Besides, vegetable and livestock production, pond fish farming, and processing of agricultural products are the highly promising trends of the Don region's inter-sectoral complex. Over 20 per cent of the Southern Federal District agricultural production accounts for the Rostov region.

The territory of the Rostov region is divided into six agricultural zones (see Fig. 1) depending on their economic and geographical location, soil and climate factors, trends and intensity of agricultural production.

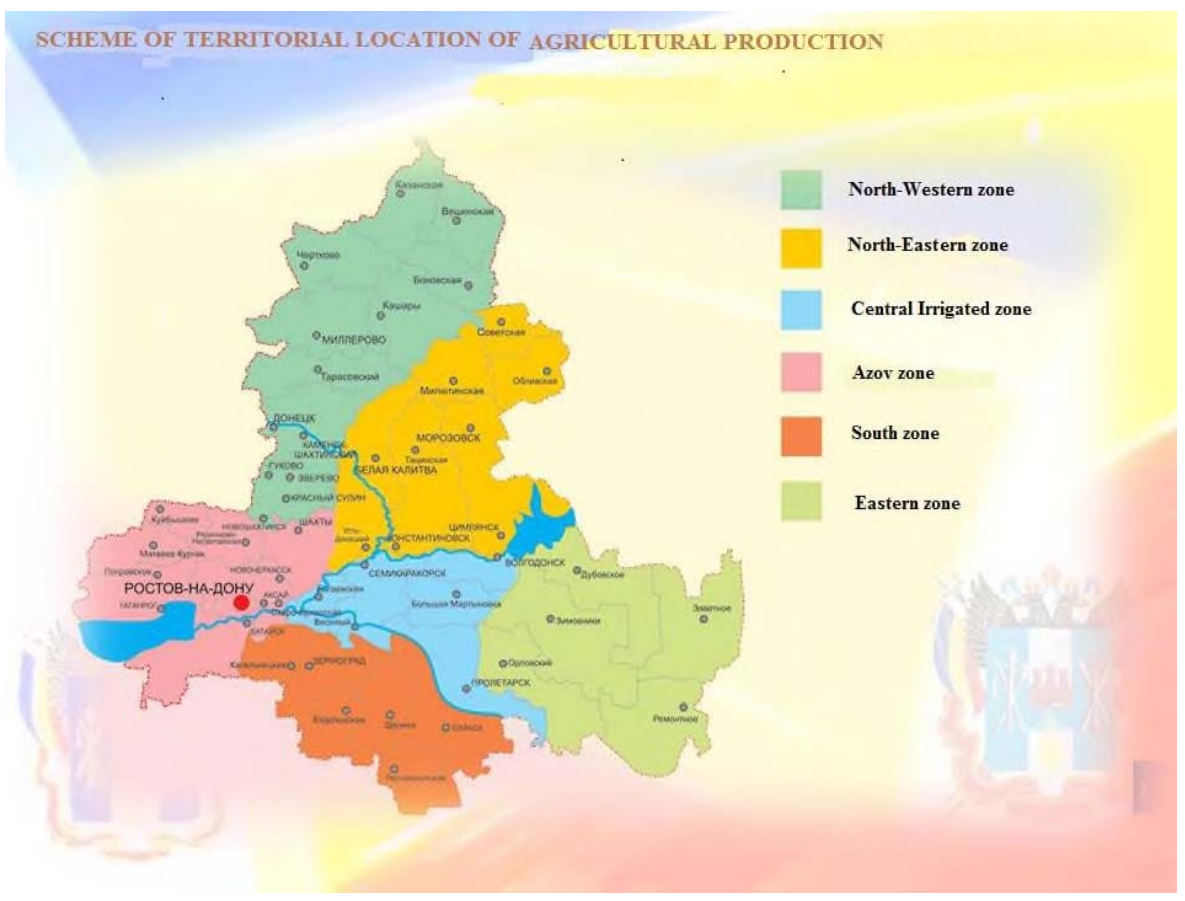

Fig.1. Agricultural map of the Rostov region

Most of the region's gross output $(65 \%)$ is produced by the crop sector. It is based on increasing the level of farming [3], introducing new varieties and hybrids of oilseeds and grains, modern energy-saving devices and equipment as well as improving the productivity of agricultural land.

\section{Results}

Grain production is of primary importance in crop growing, thanks to which the Don region has been in the top three Russian cities for several years. In the Don region, over $67 \%$ of the cultivated area is allocated for grain crops, the main of which is winter wheat. In addition, part of the areas under crops is dedicated to the cultivation of corn, buckwheat, soybean, millet, spring barley and peas. Annual cereal harvest averages 6-7 million tones, and sunflower production reaches 1.5 million tones.

Apart from agricultural produce, the Don Region is also a supplier of products of metallurgy and mechanical engineering to the European Community. In addition, the region has the potential to develop a redistribution base aimed at selling both its own products and export goods [4].

\subsection{Indicators of sustainable land use in the Rostov region}


According to the State Register data, as of 1 January 2020, the Land Fund of the Rostov region amounts to $10,096,700$ hectares.

Lands for agricultural purposes cover a total area of 8,863.7 thousand ha, settlements 450.6 thousand ha, forest fund - 344.8 thousand ha, water fund - 217.3 thousand ha, reserves -108.8 thousand ha, industry and other special purpose land - 100.1 thousand ha, specially protected natural areas and objects -11.4 thousand ha (Figure 2).

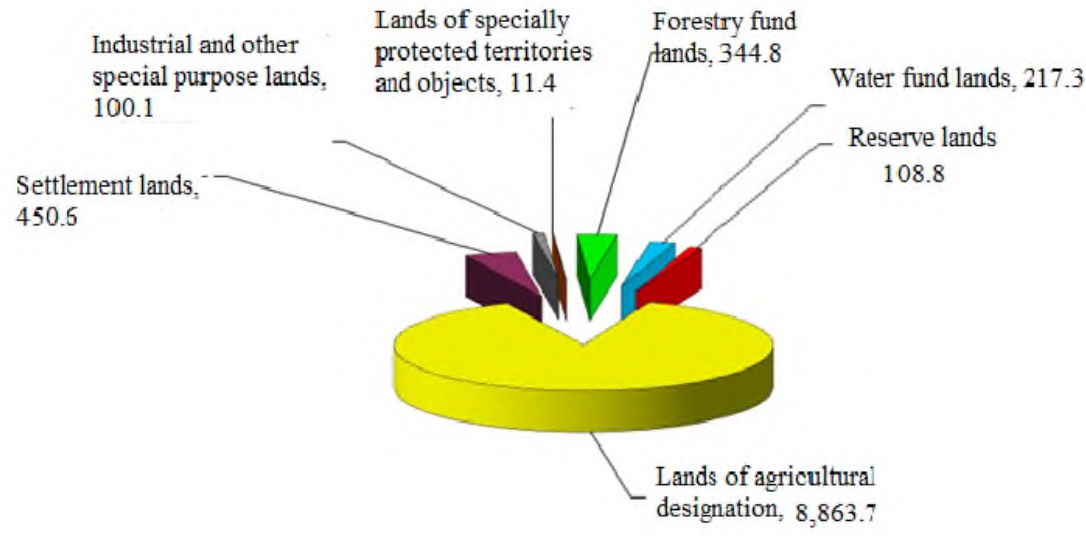

Fig. 2. Distribution of the Rostov region land fund by land category as of 1 January 2020

As a percentage, most of the territory is occupied by agricultural land $-87.7 \%$ of its total area, $4.4 \%$ of the total area is occupied by residential land, $3.4 \%$ by forest, $2.1 \%$ by water and $1.0 \%$ by reserves $[5,6]$. Lands of industry and other special purpose account for $1.0 \%$ of the total territory of the Rostov region, the remaining $0.1 \%$ are allocated to lands of specially protected territories and objects.

The breakdown of the Rostov region land fund by sites (in thousand ha) is presented in Table 1 .

Table 1. The breakdown of the Rostov region land fund.

\begin{tabular}{|l|l|l|l|r|}
\hline \multirow{2}{*}{ No. Site } & \multicolumn{1}{|c|}{} & \multicolumn{2}{c|}{ Years } & \multicolumn{2}{c|}{$\begin{array}{c}\text { Difference }+/- \\
\text { between } \\
\text { 2018 and 2019 }\end{array}$} \\
\cline { 3 - 5 } & \multicolumn{1}{|c|}{2018} & 2019 & 5 \\
\hline 1 & \multicolumn{1}{|c|}{3} & 4 & -0.7 \\
\hline 1. & $\begin{array}{l}\text { Farmland }- \\
\text { Total }\end{array}$ & $8,510.8$ & $8,510.1$ & +5.9 \\
\hline & including the following: & & & -0.1 \\
\hline & Arable land & $5,947.4$ & $5,953.3$ & -6.5 \\
\hline & Perennial plantings & 57,9 & 57.9 & -0.4 \\
\hline & Hayfields & 88.1 & 88.0 & - \\
\hline & Pastures & $2,417.4$ & $2,410.9$ & +0.5 \\
\hline 2. & Land in the process of reclamation & 17.5 & 17.1 & - \\
\hline 3. & Forest land & 293.0 & 293.0 & +0.6 \\
\hline 4. & $\begin{array}{l}\text { Forest plantations (under tree and } \\
\text { shrub vegetation) }\end{array}$ & 282 & 282.5 & +0.2 \\
\hline 5. & Underwater & 346.1 & 346.1 & -0.2 \\
\hline 6. & Building land & 152 & 152.6 & +0.2 \\
\hline 7. & Under roads & 220.5 & 220.7 & -0.2 \\
\hline 8. & Wetlands & 55.2 & 55.0 & \\
\hline 9. & Disturbed lands & 7.7 & 7.9 & 211.7 \\
\hline 10. & Other lands & 211.9 & 21.9 & \\
\hline & Total: & $10,096.7$ & $10,096.7$ & \\
\hline & & & & \\
\hline
\end{tabular}


As of 1 January 2020, agricultural land in all categories amounted to 8,510.1 thousand ha or $84.3 \%$ of the Region's land fund. Non-agricultural land represented 1,586.6 thousand ha or $15.7 \%$.

The change in the number of land sites was caused by land redistribution between categories.

In the reporting year, the area of agricultural land in all categories comprised 8,510.1 thousand ha, and their share in the regional land fund structure was $84.3 \%$, including arable land - 5,953.3 thousand ha, perennial plantings - 57.9 thousand ha, hayfields - 88.0 thousand ha and pastures $-2,410.9$ thousand ha [7].

Having analyzed the share of farmland in various categories of land in the Rostov region, we can see that the majority of farmland, namely 8,209.6 thousand ha or $96.5 \%$, referred to the category of agricultural land. And in the category of settlement land the area of this land is 235.1 thousand ha or $2.8 \%$, in the category of reserve land -29.6 thousand ha or $0.3 \%$, in the category of forest fund -23.3 thousand ha or $0.3 \%$. In all other land categories there were 12.5 thousand ha, which is about $0.1 \%$.

In 2019, there was a decline in the use of agricultural land by business associations, agricultural cooperatives and other companies by 10,000 ha, while the use of arable land decreased by 12,300 ha and pastureland increased by 2,400 ha. The main reason for this was the bankruptcy of farms [8], transfer of land plots to farms and citizens, and provision of pastures from district redistribution funds.

\section{Discussion}

\subsection{Current soil zoning in the Rostov region}

According to the procedure for natural and agricultural land zoning, the Rostov region is located in the temperate zone and falls into two zones: steppe with common and southern black earth and dry zone with dark-chestnut and chestnut soils. Black earths predominate in the soil structure of the Don Region [9-10], covering an area of 5,347,000 ha, which is $57.9 \%$ of the total area of the region (Figure 3).

According to a previously conducted qualitative assessment of land in Russia, the Rostov region ranks 13th among other regions of the Federation in terms of agricultural land quality and 10th in terms of arable land quality. However, the opposite side of high production levels is soil degradation. The soil cover, as a result of intensive cultivation and ploughing, is subject to serious anthropogenic and technological impacts, which have a devastating impact on soil fertility [11].

The monitoring of the condition and use of land in the Don region, which was carried out in 2019, revealed that despite the annual measures taken to eliminate or diminish the impact on land resources, soil destruction processes continue to expand and progress at an equally rapid pace. 


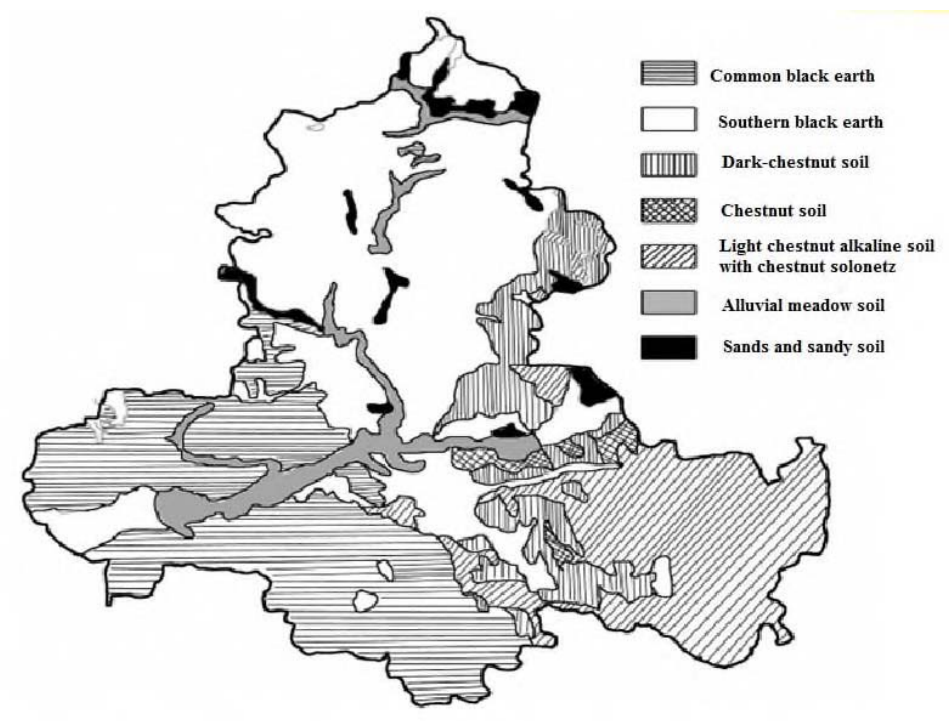

Fig. 3. Soil map of the Rostov region

\subsection{Negative soil processes and their impact on soil productivity}

Among the destructive processes observed in the Rostov region there are soil blowing, which prevails in the southern and eastern parts of the region, and soil erosion by water - in the northern and central parts, as well as their joint manifestation resulting in such negative processes as soil salinization, alkalinization, overmoisturizing, desertification and waterlogging [12]. As mentioned above, the yield of soils exposed to wind and water erosion is subject to severe fluctuations in time and space as the chemical and physical properties of the soil change.

Yields on soils subject to high erosion are reduced by $75-90 \%$, to moderate erosion - by $35-60 \%$, and weak erosion - by $15-40 \%$ [13]. For example, on highly and moderately eroded soils the productivity of barley, silage, grain, corn, winter and spring wheat can be reduced by $50 \%$.

It was found that in soils of varying degrees of erosion, the yield of agrarian crops decreased by $10-60 \%$ on average compared to non-eroded soils. Crops that are more responsive to increased degree of erosion include potatoes, millet, sunflower, buckwheat, sugar beet, while perennial grasses, on the contrary, are less responsive to soils erosion.

In addition, soil erosion causes other equally damaging negative processes, which also need to be given great attention in order to avoid large scale manifestations and spread. No less damaging to the productivity of land resources is the disruption to the natural water balance of an area.

In eroded lands, there is progressive drying out of the area, as unregulated surface runoff of melt and rain water leads to an annual loss of more than $50 \%$ moisture.

It has been calculated that a stable harvesting of grain crops of about $50-60 \mathrm{c} / \mathrm{yr}$ is mainly achieved with precipitation of at least $500-700 \mathrm{~mm} / \mathrm{yr}$ and soil moisture of at least $60-70 \%$ [14]. For this reason, agricultural and reclamation measures must be taken on eroded soils in order to improve the water permeability of the soil, improve the quality of the soil structure and ensure moisture retention.

As the number of different factors (ecological, economic, natural, social) affecting crop productivity is very high, it is necessary to take into account the existing factors when carrying out economic assessment measures aimed at preserving, improving and 
reproducing the fertile soil layer, as well as protecting and using the natural potential in a rational way [15].

Based on the analysis of the intensity in the Rostov region, the following erosion processes have been established: erosion-safe land in floodplains and sub-surface terraces; moderate and high degree of water erosion, joint manifestation of water and wind erosion of various intensity, wind erosion with appropriate allocation of soil erosion areas; a map of the Rostov region erosion zoning has been drawn up (see Figure 4).

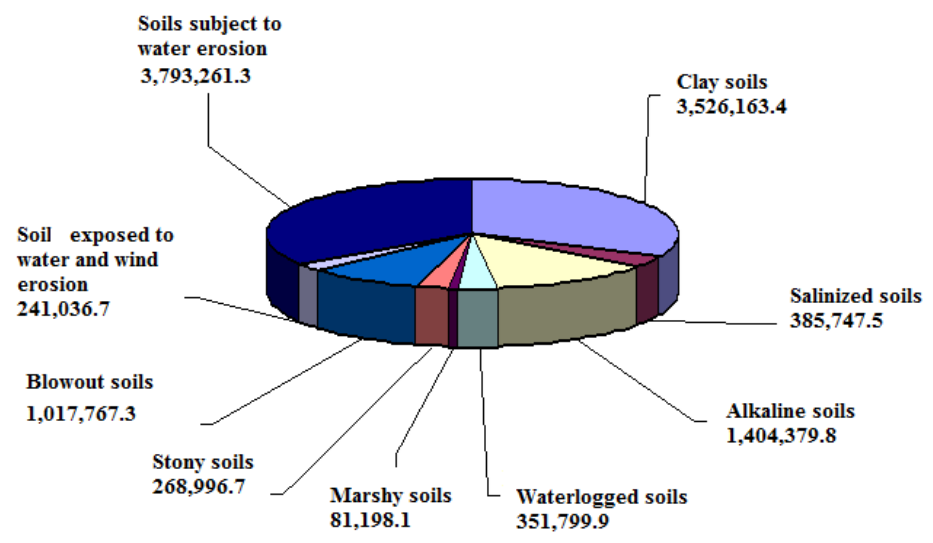

Fig. 4. Erosion zoning map of the Rostov region

\section{Conclusions}

The situation observed in the Rostov region with regard to the development of erosion processes requires great attention and urgent measures to be taken for systematic monitoring of land as the main means of assessing and projecting changes in its condition in order to develop measures to preserve and improve the conditions for the use of land resources in the region, as well as to prevent and eliminate soil destructive processes.

\section{References}

1. Immovable Property Cadastre, Cadastral activity in Russia: Experience of the present and prospects of the future, The 6th All-Russian Congress of Cadastral Engineers (SRO «Cadastral Engineers», Moscow, 2017)

2. M. Ogryzek, R. Wisniewski, T. Kauko, Real Estate Management and Valuation, 26(3) (2018) https://doi.org/10.2478/remav-2018-0022

3. N. Ovchinnikova, D. Burdova, M. Garanova, E3S Web of Conferences, 91, (2019) https://doi.org/10.1051/e3sconf/20199108023

4. T. S. Wilson, B. M. Sleeter, R. R. Sleeter, C. E. Soulard, Land, 3(2) (2014) https://doi.org/10.3390/land3020362

5. J. Wójcik-Leńa, K. Sobolewska Mikulska, N. Sajnóg, P. Leń, Land Use Policy, 78 (2018) https://doi.org/10.1016/j.landusepol.2018.06.044

6. W. Han, X. Zhang, X. Zheng, Land Use Policy, 92 (2020) https://doi.org/10.1016/j.landusepol.2019.104432

7. N. G. Ovchinnikova, MATEC Web of Conferences, 10.1051/matecconf/201710601004 
8. N. G. Ovchinnikova, Terra economicus, 7(2), 41-44 (2009)

9. V. A. Chudovska, Balanced Nature Using, Institute of agroecology and environmental management, 7(4) (2016)

10. S. Lai, F. Leone, C. Zoppi, Sustainability, 9(12) (2017) https://doi.org/10.3390/su9122174

11. S. G. Sheina, A. Khamavova, Procedia Engineering, 150 (2016) https://doi.org/10.1016/j.proeng.2016.07.198

12. O. Mertz, C. F. Mertens, World Development, 98 (2017) https://doi.org/10.1016/j.worlddev.2017.05.002

13. M. Lengoiboni, C. Richter, Jaap Zevenbergen, Land Use Policy, 85 (2019) https://doi.org/10.1016/j.landusepol.2019.03.023

14. B. Gilbey, J. Davies, G. Metternicht, C. Magero, Environmental Science \& Policy, 100 (2019) https://doi.org/10.1016/j.envsci.2019.04.007

15. D. Smiraglia, T. Ceccarelli, S. Bajocco, L. Salvati, L. Perini , Environmental Research, 147 (2016) https://doi.org/10.1016/j.envres.2015.11.030 